\title{
Enhanced Erinacine A Production by Hericium erinaceus Using Solid-State Cultivation
}

\author{
Po-Yu Cheng ${ }^{1}$, Hung-Yi Liao ${ }^{1}$, Chia-Hung Kuo ${ }^{2,3, * \mathbb{D}}$ and Yung-Chuan Liu ${ }^{1, * \mathbb{D}}$ \\ 1 Department of Chemical Engineering, National Chung Hsing University, Taichung 402, Taiwan; \\ albert1994albert1994@gmail.com (P.-Y.C.); andytoo12345678@gmail.com (H.-Y.L.) \\ 2 Department of Seafood Science, National Kaohsiung University of Science and Technology, \\ Kaohsiung 811, Taiwan \\ 3 Center for Aquatic Products Inspection Service, National Kaohsiung University of Science and Technology, \\ Kaohsiung 811, Taiwan \\ * Correspondence: kuoch@nkust.edu.tw (C.-H.K.); ycliu@dragon.nchu.edu.tw (Y.-C.L.); \\ Tel.: +886-7-3617141 (ext. 23646) (C.-H.K.); +886-4-22853769 (Y.-C.L.)
}

Citation: Cheng, P.-Y.; Liao, H.-Y.;

Kuo, C.-H.; Liu, Y.-C. Enhanced

Erinacine A Production by Hericium erinaceus Using Solid-State

Cultivation. Fermentation 2021, 7, 182.

https://doi.org/10.3390/

fermentation7030182

Academic Editor: Yi-huang Hsueh

Received: 11 August 2021

Accepted: 1 September 2021

Published: 5 September 2021

Publisher's Note: MDPI stays neutral with regard to jurisdictional claims in published maps and institutional affiliations.

Copyright: (c) 2021 by the authors. Licensee MDPI, Basel, Switzerland. This article is an open access article distributed under the terms and conditions of the Creative Commons Attribution (CC BY) license (https:// creativecommons.org/licenses/by/ $4.0 /)$.

\begin{abstract}
Hericium erinaceus (HE) is a large edible medicinal fungus. Erinacine A (ErA) is a secondary metabolite presented in the mycelia of $\mathrm{HE}$, with pharmacological effects as a nerve growth factor on the central nervous system. In this study, solid-state cultivation of HE was carried out in Petri dishes and glass jars for the production of mycelial biomass and ErA. The potato dextrose agar (PDA) had the highest mycelial biomass at an optimal temperature of $25^{\circ} \mathrm{C}$, but no ErA was found in the agar media. In glass jar cultivation, the mycelial biomass and specific yield of ErA in different substrates, particle sizes, substrate weights, nitrogen sources, and inorganic salts were investigated. The ErA was purified by a self-pack silica gel column and a semi-preparative HPLC and was identified by liquid chromatography-tandem mass spectrometer. The best conditions for solid-state cultivation of $\mathrm{HE}$ when using corn kernel as substrate, particle size less than $2.38 \mathrm{~mm}$, and addition of $10 \mathrm{mM}$ $\mathrm{ZnSO}_{4}, 7 \mathrm{H}_{2} \mathrm{O}$, mycelial biomass of $50.24 \mathrm{mg}$ cell dry weight/g substrate was obtained, in addition, the specific yield of ErA could reach $165.36 \mathrm{mg} / \mathrm{g}$ cell dry weight.
\end{abstract}

Keywords: Hericium erinaceus; erinacine A; mycelial biomass; solid-state cultivation; LC-MS; purification

\section{Introduction}

Hericium erinaceus (HE), also named lion's mane, monkey head mushroom, bearded tooth, or bearded hedgehog, is a fungus belonging to the family Hericiaceae. HE is common in nature and mainly distributed in Asia, Europe, and North America. The fruiting body of HE has been well-known as an edible and medicinal mushroom for centuries in China [1,2]. Currently, many studies have found that the fruit bodies and mycelia of HE have many bioactive compounds, such as polysaccharides [3,4], hericenones [5], erinacines [6], and ergothioneine [7]. These bioactive compounds have been reported to be helpful for human health against various physiological system diseases, including the nervous system, digestive system, circulatory system, and immune system [1,8-10]. Erinacines belong to diterpenoids, a kind of secondary metabolites. Several erinacines (i.e., erinacines $\mathrm{A}-\mathrm{K}, \mathrm{P}$, and $\mathrm{Q}$ ) were isolated from $\mathrm{HE}$ mycelia, among which erinacine $\mathrm{A}$ (ErA) was found to be a special compound capable of promoting the performance of nerve growth factor (NGF) [11,12]. So far, ErA found in the mycelia of HE has been confirmed to have pharmacological effects on the central nervous system [13], i.e., long-term prevention of stroke [14], Parkinson's disease [15], Alzheimer's disease [16], depression, and nerverelated diseases such as sexual pain and presbycusis [17]. All the neurodegenerativeconcerned diseases were reported to be effectively ameliorated via the uptake of relative diterpenoids such as ErA [18].

In the literature, $\mathrm{HE}$ has been proven capable of producing biological metabolites, such as erinacines and hericenones, via submerged or solid-state cultivation $[19,20]$. Solid-state 
cultivation is particularly appropriate for filamentous fungi because it can simulate the natural culture environment. The selection of substrate is the key to achieve successful solid-state cultivation. Generally, natural substances or industrial wastes are used as substrates in solid-state cultivation. Several factors affect solid-state cultivation, such as substrate particle size, $\mathrm{pH}$, relative humidity, additives (nitrogen source, carbon source, or salt) [21,22]. Solid-state cultivation has several advantages, including not being easily contaminated, low cost, high yield, low energy consumption, low organic wastewater generation, easy disposal of waste, and convenient source of culture medium [23].

There are few studies concerning the production of ErA from HE mycelia in submerged or solid-state cultures. In addition, it is interesting that erinacines such as ErA can only be found in the HE mycelial state but not in the fruiting body [16,24]. Valu et al. designed a medium containing yeast extract, glucose, soy powder, and oats and found it could enrich the yield of HE's total phenolic compounds; however, no ErA content was quantitatively detected [6]. Krzyczkowski et al. designed a medium containing both glucose and casein to achieve high HE mycelial biomass with ErA production at day 8 [25]. Chang et al. varied the former medium composition to enhance the HE biomass and erinacines yields [26]. Gerbec et al. reported that when cultivating HE in solid-state in a glass jar, the HE mycelial biomass could produce some ErA content; however, in a horizontal stirred tank reactor with aeration, higher biomass but no ErA content was found in the mycelia [27]. In other HE solid-state cultures, it was noted that the common substrates used to grow $\mathrm{HE}$ were based on wood chips, which might be favor the HE fruiting body and extracellular enzymes production; however, no ErA content was detected $[27,28]$. At present, there is little literature focusing on the production of ErA from HE mycelia in solid-state cultivation. This is the first study focusing on using solid-state cultivation of HE to improve the specific yield of ErA.

In this study, solid-state cultivation of HE in both Petri dish plates and glass jars was investigated for the production of ErA from HE mycelia. We explored the effect of different media and temperatures in Petri dish plates on HE mycelial growth. Six different grains were tested in the solid-state cultivation of HE. The effect of substrate particle size, nitrogen sources, and supplementations with either $\mathrm{NaCl}$ and $\mathrm{ZnSO}_{4}$ on the ErA yield was investigated. Both the HE mycelial biomass and the specific yield of ErA were measured. The purification and analysis methods were established for quantifying the concentration of ErA. The factors expected to promote ErA production in solid-state cultivation were exploited quantitatively.

\section{Materials and Methods}

\subsection{Strain and Chemicals}

The strain H. erinaceus MU30296 was purchased from the Biological Resources Conservation and Research Center, Food Industry Research and Development Institute, Hsinchu, Taiwan. Potato dextrose agar, malt extract, and yeast extract were obtained from Becton, Dickinson and Company, US. Polished rice, corn kernel, adlay kernel, brown rice, red bean, and sesame were purchased from local supermarkets. Other reagents were of analytical grade and obtained from local suppliers.

\subsection{Cultivation Conditions}

For cultivation on Petri dishes, a $0.25 \mathrm{~cm}^{2}$ of the HE mycelium was cut from the preculture dish and inoculated onto the tested Petri dish. The plate agar compositions were as follows: malt extract agar (MA) (g/L): glucose 18.9, malt extract 18.9, peptone 0.9, agar 15.0; yeast extract agar (YE) (g/L): yeast extract 3.0, peptone 5.0, and agar 15.0, and potato dextrose agar (g/L): glucose 20, potato starch (infusion from 200 g potato) 4.0, agar 15.0 [29]. The dish was cultured in an incubator set at $25^{\circ} \mathrm{C}$ for $10-15 \mathrm{~d}$.

To prepare the seed culture for the solid-state cultivation, 3 pieces of $4 \mathrm{~cm}^{2}$ mycelia grown in PDA for $10 \mathrm{~d}$ were cut and slightly homogenized in a sterile knife-edge bottle containing $40 \mathrm{~mL}$ distilled water for $1 \mathrm{~s}, 8$ times to obtain a uniform mycelium suspension. 
A volume of $10 \mathrm{~mL}$ of the homogenized mixture was inoculated into $100 \mathrm{~mL}$ of seed medium containing (g/L): glucose 4 , peptone 1 , yeast extract $0.2, \mathrm{MgSO}_{4} \cdot 7 \mathrm{H}_{2} \mathrm{O} 0.1$, and $\mathrm{KH}_{2} \mathrm{PO}_{4}$ 0.05. The cultivation was performed in a rotary incubator at $25^{\circ} \mathrm{C}, 100 \mathrm{rpm}$ for $7 \mathrm{~d}$. The prepared seed culture was used to inoculate the solid-state culture in a glass jar $(\Phi 12 \mathrm{~cm})$ containing varied dry solid grains, i.e., polished rice, corn kernel, adlay kernel, brown rice, red bean, and sesame. The solid media were prepared with $50 \mathrm{~g}$ grains mixed with $50 \mathrm{~mL}$ deionized (DI) water, followed by sterilization at $121{ }^{\circ} \mathrm{C}$ for $20 \mathrm{~min}$. The solid media were inoculated with a seed volume to grain weight of $1 / 5$. The culture was performed in an incubator at $25{ }^{\circ} \mathrm{C}$ for $20 \mathrm{~d}$. In the grain weight test, the grain to water ratio (w/v) was kept at 1:1. For grain particle sizes tests, the corn kernel was ground into powder via a blender, followed by being separated via two sieves, i.e., mesh5 and mesh8, to obtain three different particle size distributions: large particle $(>4 \mathrm{~mm})$, middle particle $(2.38-4 \mathrm{~mm})$, and small particle $(<2.38 \mathrm{~mm})$. In the additives tests, $0.25-1.5 \mathrm{~g}$ casein, $0.25-1.5 \mathrm{~g}$ tryptone, or $1 \mathrm{~mL}$ of the tested additives (10-40 mM NaCl, $10-40 \mathrm{mM}$ $\mathrm{ZnSO}_{4} \cdot 7 \mathrm{H}_{2} \mathrm{O}$ ) was supplemented to the jar containing $50 \mathrm{~g}$ of grains plus $50 \mathrm{~mL}$ DI water.

For submerged culture, the above-mentioned seed culture was inoculated (v/v ratio $1 / 10$ ) to sterile liquid medium containing (g/L): glucose $70, \mathrm{NH}_{4} \mathrm{NO}_{3} 8, \mathrm{NaCl} 1.45$, $\mathrm{ZnSO}_{4} \cdot 7 \mathrm{H}_{2} \mathrm{O} 0.055$ and $\mathrm{KH}_{2} \mathrm{PO}_{4} 1$ [25]. The culture was performed in a shaking incubator at $25{ }^{\circ} \mathrm{C}$ and $100 \mathrm{rpm}$ for $20 \mathrm{~d}$. The medium composition and cultivation conditions for the submerged culture were collected from the optimal conditions in the pre-test studies.

\subsection{Erinacine A Purification}

To obtain self-purified erinacine $A$ as the standard, the approach of Krzyczkowski et al. [25] was adopted and modified; it is described in brief as follows. The harvested mycelium was dried and ground into powder with a mortar, and then $1 \mathrm{~g}$ of the powder was added to $75 \mathrm{~mL}$ of $95 \%$ ethanol and extracted with ultrasonic shaking for $1 \mathrm{~h}$. The extract was centrifuged at $9000 \mathrm{~g}$ for $10 \mathrm{~min}$, followed by filtration via a $0.22 \mu \mathrm{m}$ filter, and subjected to concentration under vacuum. The extract was re-dissolved in $8 \mathrm{~mL}$ of ethyl acetate, followed by the addition with $2 \mathrm{~mL}$ of deionized water and mixing in an ultrasonic bath for $20 \mathrm{~min}$. The ethyl acetate layer was rinsed with 5\% sodium chloride solution. The ethyl acetate layer was separated and filtered via a $0.22 \mu \mathrm{m}$ disc filter and dried in an oven at $50{ }^{\circ} \mathrm{C}$ overnight. After drying, the extract was re-dissolved in $95 \%$ ethanol $(0.2 \mathrm{~g}$ solid plus $1 \mathrm{~mL}$ ethanol), filtered with a $0.22 \mu \mathrm{m}$ disc filter, and injected into a self-pack silica gel column. A solvent of ethyl acetate and n-hexane (1:1) was used as the mobile phase with a flow rate of $5 \mathrm{~mL} / \mathrm{min}$. The eluted solvent was collected in test tubes, one sample per minute. The collected samples were dried in a $50{ }^{\circ} \mathrm{C}$ oven, followed by the addition of $1 \mathrm{~mL}$ of ethanol to re-dissolve the sample. The sample at the 25 th min with the highest absorbance at $340 \mathrm{~nm}$ was collected. The collected sample was further subjected to a semi-preparative HPLC as described in brief as follows. The sample $(0.1 \mathrm{~g})$ was dissolved in $1 \mathrm{~mL}$ of methanol and mixed for $1 \mathrm{~h}$ in an ultrasonic bath. The extract was centrifuged at $7000 \mathrm{~g}$ for $10 \mathrm{~min}$. The supernatant was filtered via a $0.22 \mu \mathrm{m}$ disc filter and subjected to a semi-preparative high-performance liquid chromatography. The column is Inspire C18, $5 \mu \mathrm{m}(250 \mathrm{~mm} \times 10.0 \mathrm{~mm})$, detector: UV $340 \mathrm{~nm}$, flow rate: $3.0 \mathrm{~mL} / \mathrm{min}$, mobile phase: $80 \%$ methanol, sample injection $200 \mu \mathrm{L}$. The sample at $23.583 \mathrm{~min}$ with an absorption peak (wavelength: $340 \mathrm{~nm}$ ) was collected and dried in an oven at $50{ }^{\circ} \mathrm{C}$ overnight. The obtained crystal was subjected to a liquid chromatography-tandem mass spectrometer (TSQ Altis, Thermo Scientific, Waltham, MA, USA) with electrospray ionization (ESI) for identification [27].

\subsection{Assays}

To determine the dry weight (DW) of cell biomass in submerged culture, the whole culture medium was harvested and washed two times with DI water, followed by drying in an oven set at $50{ }^{\circ} \mathrm{C}$ for $5 \mathrm{~d}$. The mycelial growth in the Petri dish was estimated by detecting the image of the mycelium-covered area and transformed to the hydraulic 
radius $(\mathrm{mm})=$ square root of (biomass coverage surfaces $/ \pi$ ) via ImageJ software (National Institutes of Health, Hamilton, MT, USA). To determine the biomass in the solid-state culture, the harvested substrate was subjected to an analysis of its ergosterol content via the HPLC method [30]. A linear correlation between the HE biomass (mg cell DW/g substrate) and the ergosterol content was constructed. The ergosterol assay is described in brief as follows: $1 \mathrm{~g}$ of the ground dry substrates was subjected to extraction with $12 \mathrm{~mL}$ of $\mathrm{n}$ hexane, followed by a 90-s vortex mixing and centrifugation at $7000 \times g$ for $10 \mathrm{~min}$ to obtain the supernatant. The supernatant was subjected to vacuum drying at $40{ }^{\circ} \mathrm{C}$, followed by dissolving with $5 \mathrm{~mL}$ methanol and filtration via a $0.22 \mu \mathrm{m}$ disc filter. The collected sample was analyzed via an HPLC (Column: SCpak, $5 \mu \mathrm{m} \mathrm{C18,} 250 \mathrm{~mm} \times 4.6 \mathrm{~mm}$ ), detector (Jusco: UV-1575): UV $282 \mathrm{~nm}$, flow rate: $1.2 \mathrm{~mL} / \mathrm{min}$, mobile phase: methanol, column temperature: $40^{\circ} \mathrm{C}$, injection volume: $20 \mu \mathrm{L}$.

For the ErA assay, $1 \mathrm{~g}$ of the ground substrate was subjected to extraction with $10 \mathrm{~mL}$ methanol. The mixture was left for an ultrasound mixing for $3 \mathrm{~min}$ and centrifugation at $7000 \times g$ for $10 \mathrm{~min}$. The supernatant was filtered via a $0.22 \mu \mathrm{m}$ disc filter and analyzed by an HPLC (Column: SCpak, $5 \mu \mathrm{m} \mathrm{C18,} 250 \times 4.6 \mathrm{~mm}$ ), detector (Jusco: UV-1575): $340 \mathrm{~nm}$, mobile phase: $80 \%$ methanol, flow rate: $1.0 \mathrm{~mL} / \mathrm{min}$, column temperature: $25^{\circ} \mathrm{C}$, injection volume: $10 \mu \mathrm{L}$. The specific ErA yield was defined as mg ErA /g cell DW.

\subsection{Statistical Analysis}

All the experiments were performed in triplicate; data are expressed as means $\pm \mathrm{SD}$ (standard deviation). The statistical significance was assessed by the multiple comparisons Tukey post-hoc analysis of variance (ANOVA) using OriginPro ver.9.0 (OriginLab Corporation, Northampton, MA, USA). Differences of the results were considered statistically significant at $p$-values $<0.05$ or $p$-values $<0.01$.

\section{Results and Discussion}

\subsection{Solid-State Cultivation of HE in Petri Dish \\ 3.1.1. Effect of Media on Mycelial Growth}

Three media, PDA, MA, and YE, were prepared for HS mycelial growth in the Petri dish plate in order to observe the growth of mycelium and the optimal culture temperature. The cultivation was carried out for $30 \mathrm{~d}$, and the mycelial growth rate was recorded every $5 \mathrm{~d}$. The growth patterns of HS mycelia are shown in Figure 1. The HS mycelia exhibited the most growth on the PDA plate as compared to the other two media. The time curve of mycelium growth is represented by the hydraulic radius, as shown in Figure 2a. The HE mycelial on the PDA plate grew rapidly at day 5 and reached the full plate at day 20, where the hydraulic radius was $38.1 \mathrm{~mm}$ (Petri dish radius is $42.5 \mathrm{~mm}$ ). After $20 \mathrm{~d}$, the HE growth entered a stationary phase due to the PDA plate being full of mycelia; the color of HE mycelia changed from white to light yellow. In comparison, the HE growth in the MA plate and YE plate was much slower than that of the PDA plate at day 5 and day 10, and HS mycelia were not obviously seen until day 15 . The HE mycelia at day 30 displayed a hydraulic radius of $35.59 \mathrm{~mm}$ on the MA plate and $23.40 \mathrm{~mm}$ on the YE plate. Probably, the mycelia did not have enough carbon sources in YE, which caused slow or poor growth. In contrast, PDA has the fastest mycelia growth rate due to it containing $20 \mathrm{~g} / \mathrm{L}$ of dextrose plus $200 \mathrm{~g} / \mathrm{L}$ of potato infusion, which provides a sufficient carbon source for HE growth. In order to check the ErA production, the six PDA plates from b-1 to b-6 were dried in the oven to extract ErA from HE mycelia, but no ErA content was detected. This might be due to insufficient HE mycelia growth in a limited space or the ErA being inhibited when HE was cultured on the Petri dish plate. 


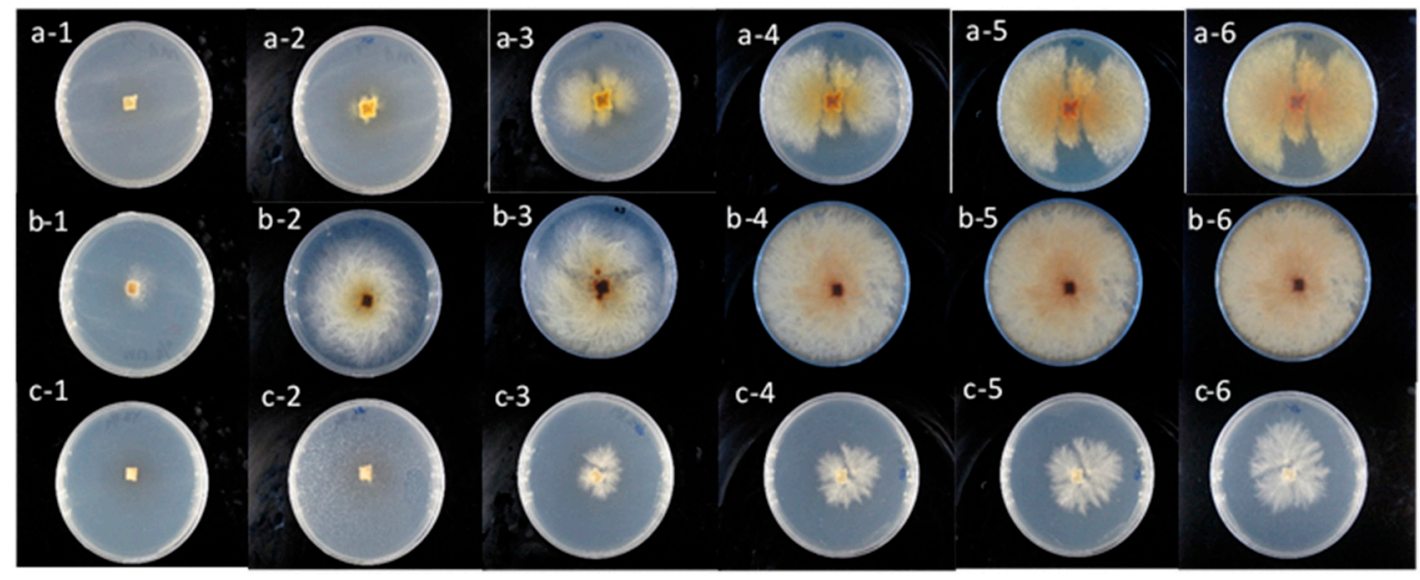

Figure 1. The growth patterns of HS mycelia on the Petri dish plate. The media used were: (a) malt extract agar medium, (b) potato dextrose agar medium, and (c) yeast extract agar medium. Numbers indicated photo records every $5 \mathrm{~d}$.

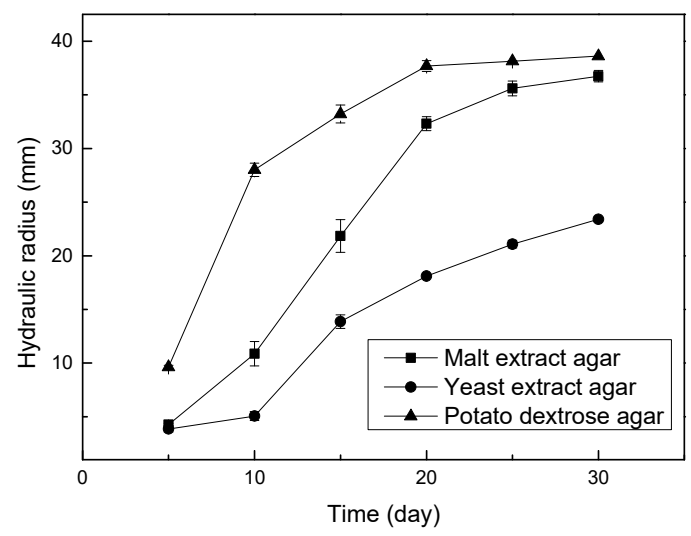

(a)

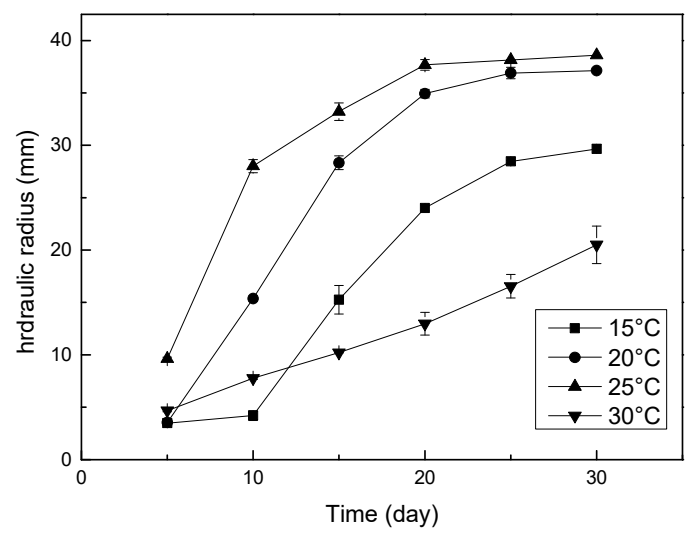

(b)

Figure 2. Effect of (a) cultivated media and (b) temperature on the hydraulic radius of HE mycelia.

\subsubsection{Effect of Temperature on Mycelial Growth}

To test the optimal temperature for HE growth, PDA plates with HE mycelial inoculum were cultured at different temperatures for $30 \mathrm{~d}$. The results are shown in Figure $2 \mathrm{~b}$. The optimum temperature for mycelial growth was $25^{\circ} \mathrm{C}$, which is consistent with Boddy et al. [31] and Ko et al. [32] findings. The HE mycelia at $25^{\circ} \mathrm{C}$ showed rapid growth at day 5 and reached a full plate at day 20. In contrast, the mycelial grew slower when the temperature was at 15 or $30^{\circ} \mathrm{C}$. On the other hand, the HE mycelia grew most slowly at $30{ }^{\circ} \mathrm{C}$, and the color of mycelia was darker than under other temperatures. It is worth mentioning that when the mycelium grows at $15^{\circ} \mathrm{C}$, it will produce a compact and stable primordium (Figure 3). Primordium is the transitional period of mycelium transforming into fruiting bodies. According to Corana's measurement [33], ErA was not found in the primordium. 


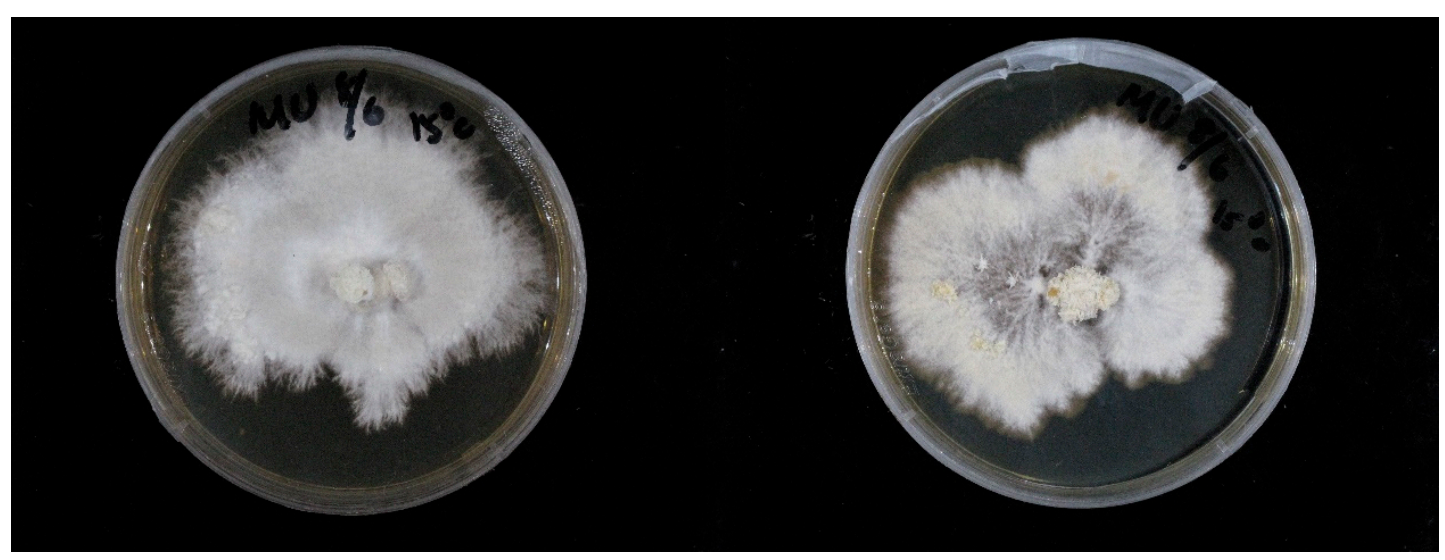

Figure 3. The formation of primordium on PDA plate at $15^{\circ} \mathrm{C}$.

\subsection{Solid-State Cultivation of HE in Glass Jar}

\subsubsection{Effect of Substrate on HE Mycelial Cultivation}

The advantage of solid-state cultivation is that the source of the substrate is convenient, such as agri-food waste or natural food crops [34,35]. Since whole grains are obtained easily and at a low cost, six different grains were selected as the substrates: polished rice, corn kernel, adlay kernel, brown rice, red beans, and sesame. The composition of these grains is listed in Table 1. The solid-state cultivation of HE was performed in a glass jar under the $50 \%$ water content for $20 \mathrm{~d}$. The results are shown in Figure 4 . The corn kernel has the highest mycelial biomass production, reaching $63.73 \mathrm{mg} \mathrm{DW} / \mathrm{g}$ substrate as compared to other substrates, and has a relatively high specific yield of ErA of $12.53 \mathrm{mg} / \mathrm{g}$ DW (or $0.798 \mathrm{mg} / \mathrm{g}$ substrate) because the corn kernel was fluffier and softer and ready for HE mycelial growth, as the rapid extension of the HE mycelium was observed in the early culture stage. In contrast, the mycelial biomass of polished rice, adlay kernel, brown rice, and red beans were $39.12 \mathrm{mg} / \mathrm{g}, 21.39 \mathrm{mg} / \mathrm{g}, 62.15 \mathrm{mg} / \mathrm{g}$, and $23.07 \mathrm{mg} / \mathrm{g}$, respectively. The results indicated high carbohydrate content increases mycelial biomass, but high lipid content reduces mycelial biomass. Because sesame is rich in oil, the HE mycelia were not easy to grow on the surface during cultivation, and the amount of biomass and ErA were too low to be detected. On the other hand, the specific yields of ErA were $13.43 \mathrm{mg} / \mathrm{g}$, $12.01 \mathrm{mg} / \mathrm{g}, 3.69 \mathrm{mg} / \mathrm{g}$, and $6.06 \mathrm{mg} / \mathrm{g}$ for polished rice, adlay kernel, brown rice, and red beans, respectively. The results indicated the lower carbon-to-nitrogen $(\mathrm{C} / \mathrm{N})$ ratio is unfavorable for ErA production. The C/N ratio of 6 to 10 has been reported to be suitable for the biosynthesis of ErA in HE mycelia [13]. Taking both biomass production and specific yield of ErA into consideration, the solid-state cultivation of HE using corn kernel as the substrate had the largest ErA production. Therefore, the corn kernel was selected as the substrate for the following experiments.

Table 1. The composition and $\mathrm{C} / \mathrm{N}$ ratio of grains in this study.

\begin{tabular}{ccccccc}
\hline $\begin{array}{c}\text { Grains } \\
\text { Composition }\end{array}$ & $\begin{array}{c}\text { Polished } \\
\text { Rice }\end{array}$ & $\begin{array}{c}\text { Corn } \\
\text { Kernel }\end{array}$ & $\begin{array}{c}\text { Adlay } \\
\text { Kernel }\end{array}$ & $\begin{array}{c}\text { Brown } \\
\text { Rice }\end{array}$ & $\begin{array}{c}\text { Red } \\
\text { Bean }\end{array}$ & Sesame \\
\hline Carbohydrate & $78.5^{*}$ & 72.2 & 65.9 & 76.6 & 61.5 & 17.6 \\
Protein & 6.1 & 10.9 & 13.7 & 7.4 & 20.9 & 22.2 \\
Lipid & 1.2 & 3.9 & 7.4 & 2.3 & 0.6 & 48.1 \\
water & 13.7 & 11.9 & 11.0 & 12.5 & 13.9 & 6.0 \\
Ash & 0.5 & 1.1 & 2.0 & 1.2 & 3.1 & 6.1 \\
C/N ratio & 12.87 & 6.62 & 4.81 & 10.35 & 2.94 & 0.79 \\
\hline
\end{tabular}

* The unit is weight ratio (\%) for grains composition except for $\mathrm{C} / \mathrm{N}$ ratio, data are collected from each grain manufacture company. 


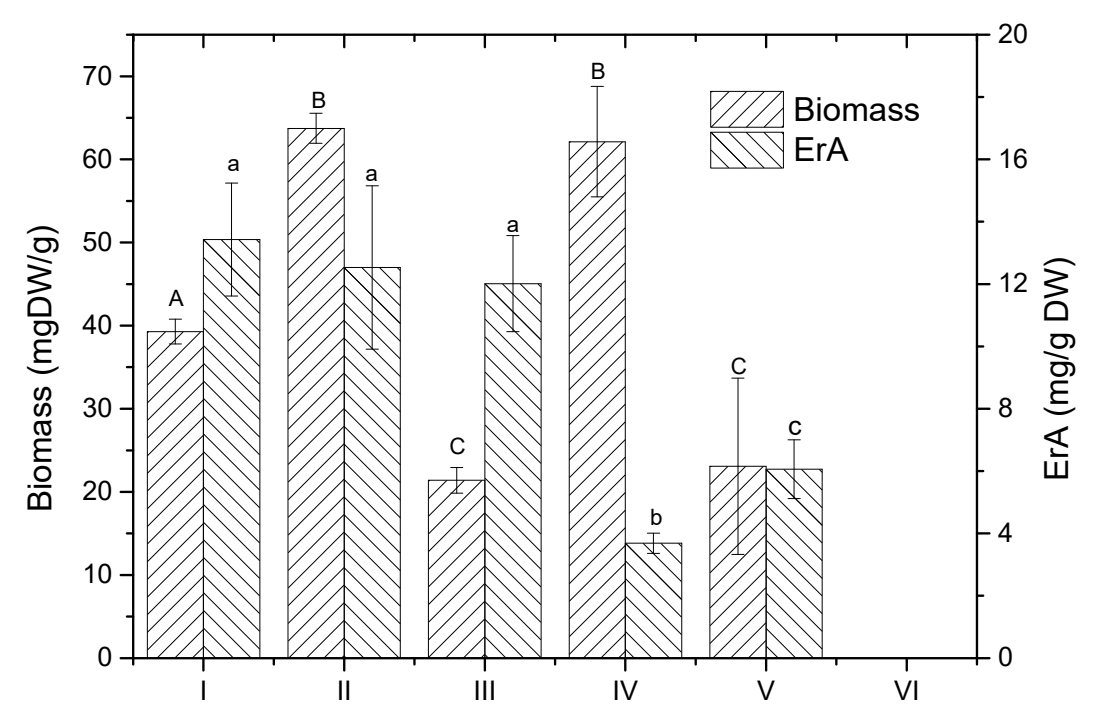

Figure 4. The effect of different substrates on the mycelial biomass and specific yield of ErA. I. polished rice, II. corn kernel, III. adlay kernel, IV. brown rice, V. red beans, VI. sesame. Different superscripts in the upper case indicate significant difference $(p<0.05)$ in biomass, and different superscripts in lower case indicate significant difference $(p<0.05)$ in specific yield of ErA.

\subsubsection{Effect of Particle Size}

In order to increase the mycelial biomass production and specific yield of ErA, several factors affecting solid-state fermentation were explored. In general, the particle size of the substrate in solid-state cultivation affected the production of mycelial biomass and fermented product. Corn kernel powder was divided into three particle sizes through sieving with two screens. The effect of substrate particle size can be seen in Figure 5 a. The mycelial biomass of large particle $(>4 \mathrm{~mm})$, middle particle $(2.38-4 \mathrm{~mm})$, and small particle $(<2.38 \mathrm{~mm})$ were $37.54 \mathrm{mg} / \mathrm{g}$, $45.88 \mathrm{mg} / \mathrm{g}$, and $57.25 \mathrm{mg} / \mathrm{g}$, respectively. The substrate particle size did not have a significant difference in mycelial biomass production. However, the specific yield of ErA increased dramatically with decreasing particle size, from $12.53 \mathrm{mg} / \mathrm{g}(>4 \mathrm{~mm})$ to $60.15 \mathrm{mg} / \mathrm{g}(<2.38 \mathrm{~mm})$. The specific yield of ErA of small particles was a 4.8 -fold increase over the large particles. Membrillo et al. produced lignocellulolytic enzymes from Pleurotus ostreatus; the highest xylanases, cellulases, and laccase activity were obtained from the substrate particle size of $2.9 \mathrm{~mm}, 0.92 \mathrm{~mm}, 1.68 \mathrm{~mm}$, respectively [36]. Smail et al. cultured the Aspergihs niger in solid-state fermentation and found that the particle size of $2.5 \mathrm{~mm}$ carob pods gave the highest protein content of the final product [37]. In our case, the small particle showed a high specific yield of ErA, perhaps due to closer packing, leading to restricted $\mathrm{O}_{2}$ availability, which in turn increased the production of secondary metabolites-ErA. Therefore, the small particles of corn kernel were used in subsequent experiments.

\subsubsection{Effect of Substrate Weight}

Because the mycelia formed a mycelium mat on the surface, the air circulation was decreased, leading to restricted $\mathrm{O}_{2}$ availability at the bottom. Thereby, increasing the substrate amounts in the glass jar was expected to increase the anaerobic space at the bottom [38]. To investigate the effect of substrate layer thickness, experiments were performed in a glass jar containing various amounts of substrate. Due to the lower part of the glass jar being cylindrical, the substrate weight is proportional to the thickness of the substrate in the glass jar, where $150 \mathrm{~g}$ substrate is equivalent to $4.5 \mathrm{~cm}$ in height. The results are shown in Figure 5b. When the substrate weight increased from $50 \mathrm{~g}$ to $150 \mathrm{~g}$, the mycelial biomass decreased from $56.79 \mathrm{mg} / \mathrm{g}$ to $31.52 \mathrm{mg} / \mathrm{g}$. The results showed that the increased substrate amount could not promote HE mycelial biomass per substrate weight. The reason is probably that the increase of substrate weight increased substrate layer thickness 
that reduced oxygen in the bottom, resulting in poor mycelial growth. Stredansky et al. reported that when the substrate thickness exceeded $6 \mathrm{~cm}$, the yield of succinoglycan from Agrobacterium tumefaciens decreased dramatically [39]. Rhizopus oryzae cultivated on bread waste has maximum protease and amylase activities at the layer thickness of $1 \mathrm{~cm}$ [40]. Besides, the highest specific yield of ErA was detected when $50 \mathrm{~g}$ of substrate was used. After $20 \mathrm{~d}$ of cultivation, the mycelia were found to penetrate into the entire jar bottom in $50 \mathrm{~g}$ substrate, while others were not completely covered by mycelia, probably due to insufficient oxygen availability.

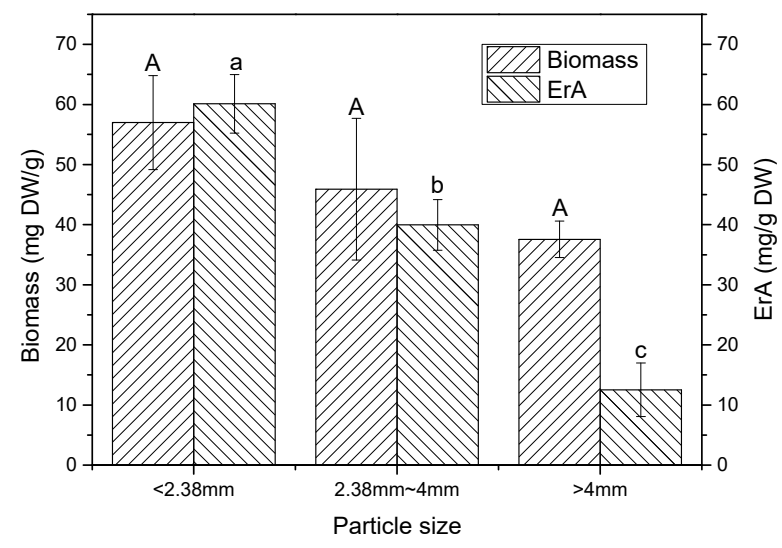

(a)

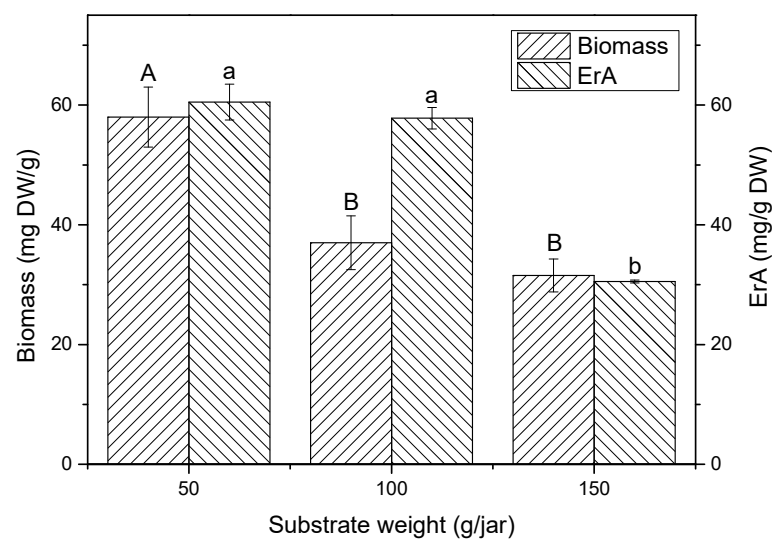

(b)

Figure 5. The effect of (a) substrate particle size and (b) substrate amount on the mycelial biomass and specific yield of ErA. Different superscripts in upper case indicate significant difference $(p<0.05)$ in biomass, and different superscripts in lower case indicate significant difference $(p<0.05)$ in specific yield of ErA.

\subsubsection{Effect of Nitrogen Source and Inorganic Salts}

The nitrogen source of the medium in submerged fermentation has a significant effect on the HE mycelial growth and ErA production [25]. Therefore, the casein and tryptone were added to the substrate in solid-stated cultivation in order to enhance the mycelial biomass and production of ErA. The effect of nitrogen source addition is presented in Figure $6 \mathrm{a}, \mathrm{b}$. The highest mycelial biomass of $80.56 \mathrm{mg} / \mathrm{g}$ (Figure $6 \mathrm{~b}$ ) was obtained by adding $5 \mathrm{mg}$ tryptone/g substrate, but the mycelial biomass decreased when the addition of casein or tryptone exceeded $5 \mathrm{~g} / \mathrm{g}$ substrate. This is consistent with findings that a low $\mathrm{C} / \mathrm{N}$ ratio is unfavorable for cell growth [13]. On the other hand, the specific yield of ErA was not improved by adding casein or tryptone. The addition of inorganic salts to the substrate has been reported to increase the production of soluble dietary fiber in the solid-state cultivation of $\mathrm{HE}$ [41]. Hence, $\mathrm{NaCl}$ and $\mathrm{ZnSO}_{4} \cdot 7 \mathrm{H}_{2} \mathrm{O}$ were added to the substrate. The effect of $\mathrm{NaCl}$ addition is shown in Figure 6c. The specific yield of ErA was significantly improved at the low $\mathrm{NaCl}$ concentrations of $10 \mathrm{mM}$ and $20 \mathrm{mM}$. The specific yield of ErA was $120.97 \mathrm{mg} / \mathrm{g}$ at $\mathrm{NaCl}$ concentration of $10 \mathrm{mM}$, which was 2-fold higher than that of the control. On the other hand, the highest mycelial biomass was $87.38 \mathrm{mg} / \mathrm{g}$ at $\mathrm{NaCl}$ concentration of $40 \mathrm{mM}$, which was 1.5-fold higher than that of the control, but the specific yield of ErA was very low. Zinc ions as trace elements provide supplementary substrates for the growth of mushrooms [42]. Lin et al. reported that trace $\mathrm{ZnSO}_{4}$ increased the production of sulfated polysaccharides from Antrodia cinnamomea [43]. The effect of $\mathrm{ZnSO}_{4} \cdot 7 \mathrm{H}_{2} \mathrm{O}$ addition is shown in Figure $6 \mathrm{~d}$. The highest specific yield of ErA was $165.36 \mathrm{mg} / \mathrm{g}$ at $\mathrm{ZnSO}_{4} \cdot 7 \mathrm{H}_{2} \mathrm{O}$ concentration of $10 \mathrm{mM}$, which was 2.73-fold higher than that of the control. The results indicated that the appropriate addition of $\mathrm{NaCl}$ or $\mathrm{ZnSO}_{4} \cdot 7 \mathrm{H}_{2} \mathrm{O}$ could help increase the production of mycelial biomass or ErA. 


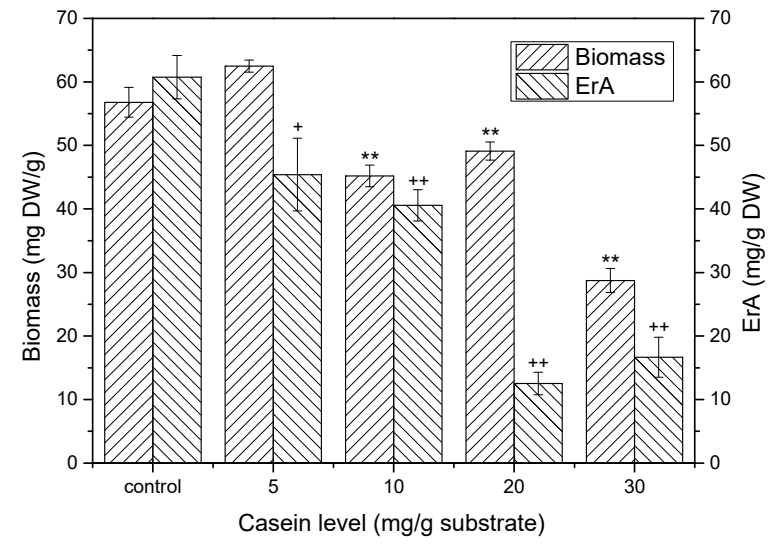

(a)

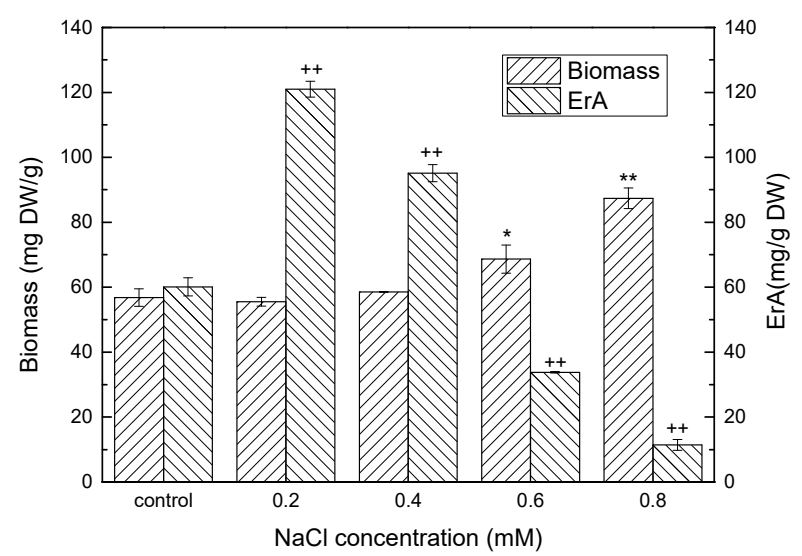

(c)

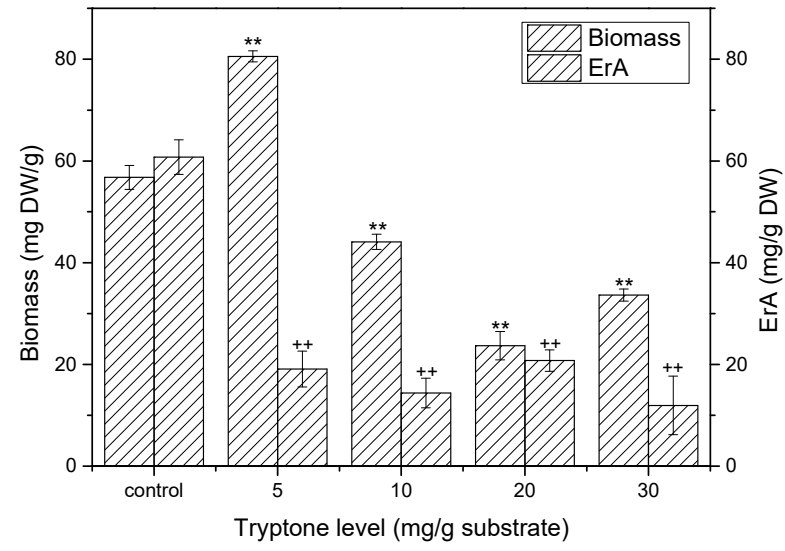

(b)

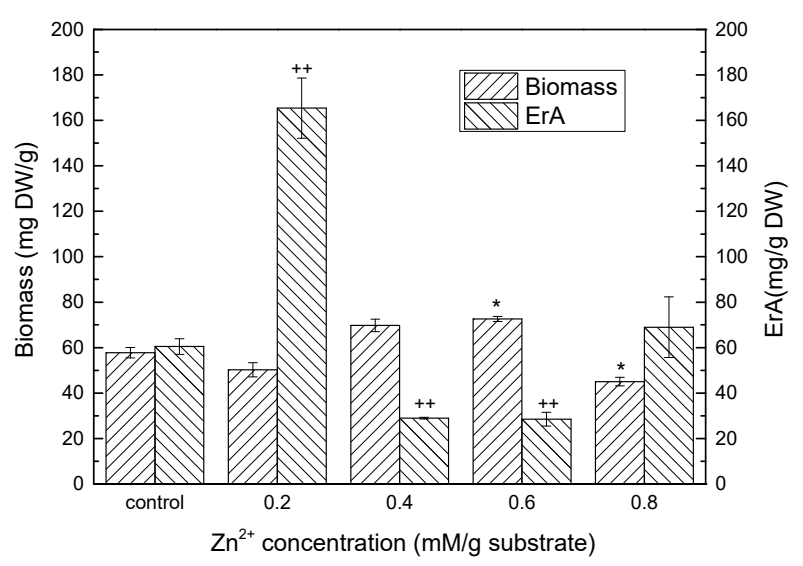

(d)

Figure 6. Effect of (a) casein, (b) tryptone, (c) $\mathrm{NaCl}$, and (d) $\mathrm{ZnSO}_{4} \cdot 7 \mathrm{H}_{2} \mathrm{O}$ addition on mycelial growth and ErA production. $*$, ** indicate biomass significant difference with control at $p<0.05$ and $p<0.01$, respectively.,+++ indicate ErA significant difference with control at $p<0.05$ and $p<0.01$, respectively.

\subsection{ErA Purification and Identification}

A self-pack silica gel column and semi-preparative HPLC method described in Section 2.3 were used to purify ErA as the standard for quantitative analysis. The purified ErA was subjected to a liquid chromatography-tandem mass spectrometer (LC/MS/MS, model TSQ Altis, Thermo Scientific, MA, USA). The ESI mass spectrum of ErA (Figure 7a) exhibited a $\mathrm{m} / \mathrm{z}$ of 455.3 for [ErA+Na] $]^{+}$, consistent with that in the literature $[27,33]$. To further confirm the result, the compound was sent to the tandem mass analysis; the major fragment of ErA was obtained at m/z of 323.2 (Figure $7 \mathrm{~b}$ ). To quantitatively analyze ErA, an HPLC method described in Section 2.4 was used. The HPLC profile of HE mycelial extract is shown in Figure 7c; ErA's absorption peak was detected at $14.15 \mathrm{~min}$ with UV/Vis detector at a wavelength of $340 \mathrm{~nm}$. 


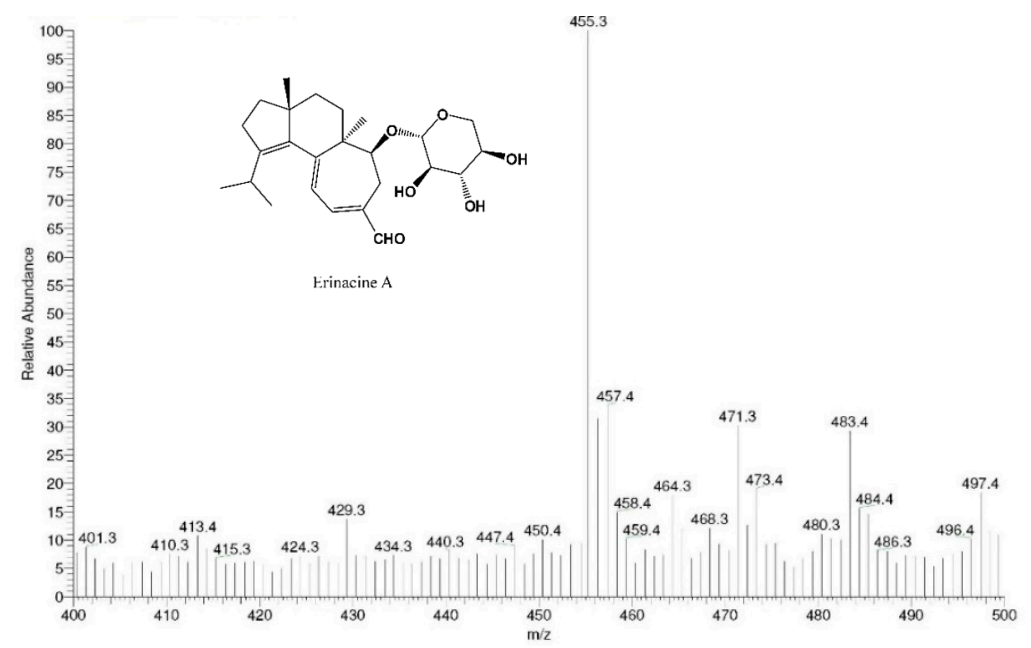

(a)

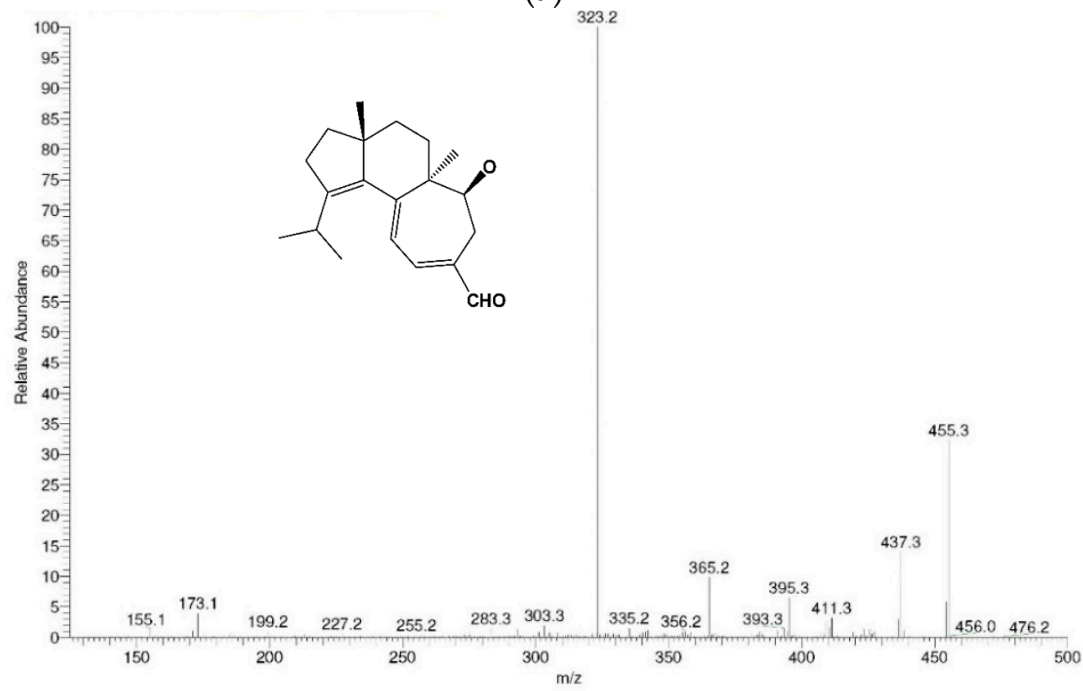

(b)

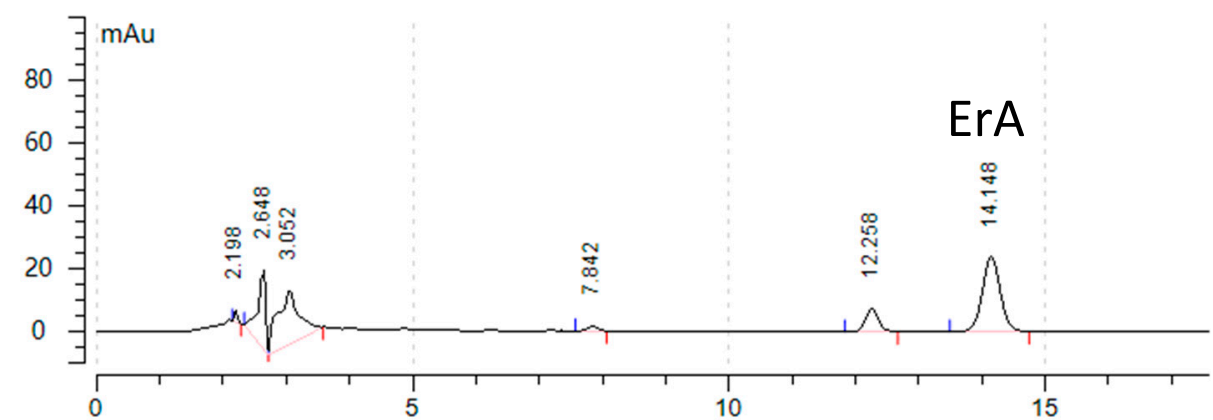

(c)

Figure 7. Analysis and identification of ErA using: (a) ESI Mass for ErA at m/z: 455.3 [M+Na] ${ }^{+}$, (b) tandem MS/MS for ErA fragment at m/z 323.2 and (c) HPLC analysis of the mycelia extract.

\subsection{Comparisons of ErA Production Using Submerged Fermentation and Solid-State Cultivation}

The extant literature focusing on ErA production is listed in Table 2. The highest specific yield of ErA using submerged cultivation of HE for $8 \mathrm{~d}$ was reported to be $14.44 \mathrm{mg} / \mathrm{g}$ and $13.39 \mathrm{mg} / \mathrm{g}[25,26]$. The specific yield of ErA produced by the fermentation tank is 5 (mg/g) $[17,44]$. Gerbec et al. cultivated HE in solid-state in a glass jar to produce ErA and was recorded by $225.4 \times 10^{3}$ (area under curve, AUC) due to a lack of ErA standard [27]. In our lab, the submerged fermentation was carried out in a shake flask using 
a glucose-based medium (Section 2.2) for the production of ErA from HE mycelia. After $12 \mathrm{~d}$ of submerged fermentation, the highest ErA production of $56.8 \mathrm{mg} / \mathrm{L}$ was obtained with mycelial biomass of $4.42 \mathrm{~g}$ DW/L (equivalent to a specific yield of ErA $12.85 \mathrm{mg} / \mathrm{g}$ DW). In this study, the Petri dish and glass jar were used for the solid-state cultivation of $\mathrm{HE}$, but ErA was only produced in the glass jar. By choosing the corn kernel as substrate and grinding the substrate to a small dimension, the specific yield of ErA was increased from $12.53 \mathrm{mg} / \mathrm{g}$ DW to $60.15 \mathrm{mg} / \mathrm{g}$ DW. It is noted that the solid-state cultivation has a higher specific yield of ErA than that in submerged culture. The appropriate addition of inorganic salts can effectively increase the production of mycelial biomass or ErA. In the case of $10 \mathrm{mM} \mathrm{ZnSO}_{4} \cdot 7 \mathrm{H}_{2} \mathrm{O}$ addition, the specific yield of ErA was significantly increased to $165.36 \mathrm{mg} / \mathrm{g}$ DW with mycelial biomass of $50.24 \mathrm{mg}$ DW/g substrate.

Table 2. Comparison of the ErA production in the literature.

\begin{tabular}{|c|c|c|c|c|c|c|}
\hline Strain & Culture State & $\begin{array}{l}\text { Specific ErA Yield } \\
(\mathrm{mg} / \mathrm{g} \text { DW) }\end{array}$ & Biomass Level ${ }^{1}$ & ErA Production ${ }^{2}$ & $\begin{array}{c}\text { Culture } \\
\text { Time (Day) }\end{array}$ & Ref. \\
\hline $\begin{array}{l}\text { H. erinaceum (Bull.: } \\
\text { Fr.) Pers. }\end{array}$ & Submerged & 14.44 & $13.3(\mathrm{~g} / \mathrm{L})$ & $192(\mathrm{mg} / \mathrm{L})$ & 8 & {$[25]$} \\
\hline $\begin{array}{c}\text { H. erinaceus BCRC } \\
35669\end{array}$ & Submerged & 13.39 & $16.8(\mathrm{~g} / \mathrm{L})$ & $225(\mathrm{mg} / \mathrm{L})$ & 8 & {$[26]$} \\
\hline $\begin{array}{c}\text { H. erinaceum BCRC } \\
35669\end{array}$ & Submerged fermenter & 5 & $\mathrm{NA}^{3}$ & NA & 12 & {$[17,33]$} \\
\hline H. erinaceus & Solid-state, glass jar & NA & $100(\mathrm{~g} / \mathrm{kg})$ & $225.4 \times \underset{4}{10^{3}} \mathrm{AUC}$ & 56 & [27] \\
\hline $\begin{array}{l}\text { H. erinaceum } \\
\text { MU30296 }\end{array}$ & $\begin{array}{l}\text { Submerged, shake } \\
\text { flask }\end{array}$ & 12.85 & $4.42(\mathrm{~g} / \mathrm{L})$ & $56.80(\mathrm{mg} / \mathrm{L})$ & 12 & This study \\
\hline $\begin{array}{l}\text { H. erinaceum } \\
\text { MU30296 }\end{array}$ & Petri dish & $\mathrm{ND}^{5}$ & ND & ND & $10-15$ & This study \\
\hline $\begin{array}{l}\text { H. erinaceum } \\
\text { MU30296 }\end{array}$ & Solid-state, glass jar & 165.36 & $50.24(\mathrm{~g} / \mathrm{kg})$ & $8.3(\mathrm{~g} / \mathrm{kg})$ & 20 & This study \\
\hline
\end{tabular}

\section{Conclusions}

This research aims at solid-state cultivation of HE for ErA production. HE was cultured in Petri dishes and glass jars. ErA was only found in the glass jar cultivation. Six different substrates were used as substrates in solid-state cultivation; the corn kernel had the highest mycelial biomass of $63.73 \mathrm{mg} / \mathrm{g}$ with a specific yield of ErA of $12.53 \mathrm{mg} / \mathrm{g}$. The particle size showed less effect on the mycelial mass, but decreasing substrate dimension significantly increased the specific yield of ErA. The substrate in small particle size reduced air flow so that ErA was less prone to degradation under the insufficient oxygen condition, which helped to increase the specific yield of ErA. Adding appropriate nitrogen sources or inorganic salts to the substrate can increase the mycelial biomass and the specific yield of ErA; the addition of $\mathrm{NaCl}$ or $\mathrm{ZnSO}_{4}$ had a significant increase in the specific yield of ErA to $120.97 \mathrm{mg} / \mathrm{g}$ and $165.36 \mathrm{mg} / \mathrm{g}$, respectively. Besides, this study provided the ErA purification and analysis method. Compared with submerged cultivation, solid-state cultivation can effectively increase the specific yield of ErA by 12.9-fold. The results in this study provide the information to scale up the solid-state cultivation of HE for ErA production.

Author Contributions: Conceptualization, Y.-C.L.; methodology, P.-Y.C. and H.-Y.L.; formal analysis, P.-Y.C.; investigation, P.-Y.C.; writing —original draft preparation, C.-H.K. and Y.-C.L.; writing—review and editing, C.-H.K. and Y.-C.L. All authors have read and agreed to the published version of the manuscript.

Funding: This research was funded by the Ministry of Science and Technology of Taiwan (grant no. MOST 108-2221-E-005-041-MY2).

Institutional Review Board Statement: Not applicable. 
Informed Consent Statement: Not applicable.

Data Availability Statement: Not applicable.

Conflicts of Interest: The authors declare no conflict of interest.

\section{References}

1. Kim, S.P.; Moon, E.; Nam, S.H.; Friedman, M. Hericium erinaceus mushroom extracts protect infected mice against Salmonella Typhimurium-Induced liver damage and mortality by stimulation of innate immune cells. J. Agric. Food Chem. 2012, 60, 5590-5596. [CrossRef]

2. Thongbai, B.; Rapior, S.; Hyde, K.D.; Wittstein, K.; Stadler, M. Hericium erinaceus, an amazing medicinal mushroom. Mycol. Prog. 2015, 14, 1-23. [CrossRef]

3. Yang, Y.; Zhao, C.; Diao, M.; Zhong, S.; Sun, M.; Sun, B.; Ye, H.; Zhang, T. The prebiotic activity of simulated gastric and intestinal digesta of polysaccharides from the Hericium erinaceus. Molecules 2018, 23, 3158. [CrossRef]

4. Zhu, L.; Wu, D.; Zhang, H.; Li, Q.; Zhang, Z.; Liu, Y.; Zhou, S.; Wang, W.; Li, Z.; Yang, Y. Effects of Atmospheric and Room Temperature Plasma (ARTP) mutagenesis on physicochemical characteristics and immune activity in vitro of Hericium erinaceus polysaccharides. Molecules 2019, 24, 262. [CrossRef]

5. Chong, P.S.; Fung, M.-L.; Wong, K.H.; Lim, L.W. Therapeutic potential of Hericium erinaceus for depressive disorder. Int. J. Mol. Sci. 2020, 21, 163. [CrossRef] [PubMed]

6. Valu, M.-V.; Soare, L.C.; Sutan, N.A.; Ducu, C.; Moga, S.; Hritcu, L.; Boiangiu, R.S.; Carradori, S. Optimization of ultrasonic extraction to obtain erinacine a and polyphenols with antioxidant activity from the fungal biomass of Hericium erinaceus. Foods 2020, 9, 1889. [CrossRef]

7. Kalaras, M.D.; Richie, J.P.; Calcagnotto, A.; Beelman, R.B. Mushrooms: A rich source of the antioxidants ergothioneine and glutathione. Food Chem. 2017, 233, 429-433. [CrossRef]

8. Shen, T.; Morlock, G.; Zorn, H. Production of cyathane type secondary metabolites by submerged cultures of Hericium erinaceus and evaluation of their antibacterial activity by direct bioautography. Fungal. Biol. Biotechnol. 2015, 2, 8. [CrossRef] [PubMed]

9. Lu, Q.-Q.; Tian, J.-M.; Wei, J.; Gao, J.-M. Bioactive metabolites from the mycelia of the basidiomycete Hericium erinaceum. Nat. Prod. Res. 2014, 28, 1288-1292. [CrossRef]

10. Han, S.S.; Cho, C.K.; Lee, Y.W.; Yoo, H.S. Antimetastatic and immunomodulating effect of water extracts from various mushrooms. J. Acupunct Meridian Stud. 2009, 2, 218-227. [CrossRef]

11. Shimbo, M.; Kawagishi, H.; Yokogoshi, H. Erinacine A increases catecholamine and nerve growth factor content in the central nervous system of rats. Nutr. Res. 2005, 25, 617-623. [CrossRef]

12. Kawagishi, H.; Zhuang, C.; Yunoki, R. Compounds for dementia from Hericium erinaceum. Drugs Future 2008, 33, 149. [CrossRef]

13. Li, I.-C.; Lee, L.-Y.; Tzeng, T.-T.; Chen, W.-P.; Chen, Y.-P.; Shiao, Y.-J.; Chen, C.-C. Neurohealth properties of Hericium erinaceus mycelia enriched with erinacines. Behav. Neurol. 2018, 2018, 1-10.

14. Lee, K.-F.; Chen, J.-H.; Teng, C.-C.; Shen, C.-H.; Hsieh, M.-C.; Lu, C.-C.; Lee, K.-C.; Lee, L.-Y.; Chen, W.-P.; Chen, C.-C. Protective effects of Hericium erinaceus mycelium and its isolated erinacine A against ischemia-injury-induced neuronal cell death via the inhibition of iNOS/p38 MAPK and nitrotyrosine. Int. J. Mol. Sci. 2014, 15, 15073-15089. [CrossRef] [PubMed]

15. Lee, K.-F.; Tung, S.-Y.; Teng, C.-C.; Shen, C.-H.; Hsieh, M.C.; Huang, C.-Y.; Lee, K.-C.; Lee, L.-Y.; Chen, W.-P.; Chen, C.-C. Post-treatment with erinacine A, a derived diterpenoid of H. erinaceus, attenuates neurotoxicity in MPTP model of Parkinson's disease. Antioxidants 2020, 9, 137. [CrossRef]

16. Li, I.; Chang, H.-H.; Lin, C.-H.; Chen, W.-P.; Lu, T.-H.; Lee, L.-Y.; Chen, Y.-W.; Chen, Y.-P.; Chen, C.-C.; Lin, D.P.-C. Prevention of early Alzheimer's disease by erinacine A-enriched Hericium erinaceus mycelia pilot double-blind placebo-controlled study. Front. Aging Neurosci. 2020, 12, 155. [CrossRef]

17. Li, I.-C.; Lee, L.-Y.; Chen, Y.-J.; Chou, M.-Y.; Wang, M.-F.; Chen, W.-P.; Chen, Y.-P.; Chen, C.-C. Erinacine A-enriched Hericium erinaceus mycelia promotes longevity in Drosophila melanogaster and aged mice. PLoS ONE 2019, 14, e0217226. [CrossRef] [PubMed]

18. Chang, S.T.; Wasser, S.P. The role of culinary-medicinal mushrooms on human welfare with a pyramid model for human health Int. J. Med. Mushrooms 2012, 14, 95-134. [CrossRef]

19. Malinowska, E.; Krzyczkowski, W.; Lapienis, G.; Herold, F. Improved simultaneous production of mycelial biomass and polysaccharides by submerged culture of Hericium erinaceum: Optimization using a central composite rotatable design (CCRD). J. Ind. Microbiol. Biotechnol. 2009, 36, 1513-1527. [CrossRef]

20. Ulziijargal, E.; Mau, J. Nutrient compositions of culinary-medicinal mushroom fruiting bodies and mycelia. Int. J. Med. Mushrooms 2011, 13, 343-349. [CrossRef] [PubMed]

21. McKinney, K.; Combs, J.; Becker, P.; Humphries, A.; Filer, K.; Vriesekoop, F. Optimization of phytase production from Escherichia coli by altering solid-state fermentation conditions. Fermentation 2015, 1, 13-23. [CrossRef]

22. Handa, S.; Sharma, N.; Pathania, S. Multiple parameter optimization for maximization of pectinase production by Rhizopus sp. C4 under solid-state fermentation. Fermentation 2016, 2, 10. [CrossRef]

23. Martins, S.; Mussatto, S.I.; Martínez-Avila, G.; Montañez-Saenz, J.; Aguilar, C.N.; Teixeira, J.A. Bioactive phenolic compounds: Production and extraction by solid-state fermentation. A review. Biotechnol. Adv. 2011, 29, 365-373. [CrossRef] [PubMed] 
24. Ma, B.-J.; Shen, J.-W.; Yu, H.-Y.; Ruan, Y.; Wu, T.-T.; Zhao, X. Hericenones and erinacines: Stimulators of nerve growth factor (NGF) biosynthesis in Hericium erinaceus. Mycology 2010, 1, 92-98. [CrossRef]

25. Krzyczkowski, W.; Malinowska, E.; Herold, F. Erinacine A biosynthesis in submerged cultivation of Hericium erinaceum: Quantification and improved cultivation. Eng. Life Sci. 2010, 10, 446-457. [CrossRef]

26. Chang, C.-H.; Chen, Y.; Yew, X.-X.; Chen, H.-X.; Kim, J.-X.; Chang, C.-C.; Peng, C.-C.; Peng, R.Y. Improvement of erinacine A productivity in Hericium erinaceus mycelia and its neuroprotective bioactivity against the glutamate-insulted apoptosis. LWT-Food Sci. Technol. 2016, 65, 1100-1108. [CrossRef]

27. Gerbec, B.; Tavčar, E.; Gregori, A.; Kreft, S.; Berovic, M. Solid-state cultivation of Hericium erinaceus biomass and erinacine: A production. J. Bioproces. Biotech. 2015, 5, 1-5.

28. Atila, F. Lignocellulosic and proximate based compositional changes in substrates during cultivation of Hericium erinaceus mushroom. Sci. Hortic. 2019, 258, 108779. [CrossRef]

29. Imtiaj, A.; Jayasinghe, C.; Lee, G.W.; Shim, M.J.; Rho, H.-S.; Lee, H.S.; Hur, H.; Lee, M.W.; Lee, U.-Y.; Lee, T.-S. Vegetative growth of four strains of Hericium erinaceus collected from different habitats. Mycobiology 2008, 36, 88-92. [CrossRef]

30. Klamer, M.; Bååth, E. Estimation of conversion factors for fungal biomass determination in compost using ergosterol and PLFA 18: 2w6, 9. Soil Biol. Biochem. 2004, 36, 57-65. [CrossRef]

31. Boddy, L.; Crockatt, M.E.; Ainsworth, A.M. Ecology of Hericium cirrhatum, H. coralloides and H. erinaceus in the UK. Fungal Ecol. 2011, 4, 163-173. [CrossRef]

32. Ko, H.G.; Park, H.G.; Park, S.H.; Choi, C.W.; Kim, S.H.; Park, W.M. Comparative study of mycelial growth and basidiomata formation in seven different species of the edible mushroom genus Hericium. Bioresour. Technol. 2005, 96, 1439-1444. [CrossRef]

33. Corana, F.; Cesaroni, V.; Mannucci, B.; Baiguera, R.M.; Picco, A.M.; Savino, E.; Ratto, D.; Perini, C.; Kawagishi, H.; Girometta, C.E. Array of metabolites in Italian Hericium erinaceus mycelium, primordium, and sporophore. Molecules 2019, 24, 3511. [CrossRef]

34. Lee, G.Y.; Li, W.; Chirwa, U.M.; Shi, J. Effect of substrate characteristics on the growth and sporulation of two biocontrol microorganisms during solid-state cultivation. Fermentation 2020, 6, 69. [CrossRef]

35. Szymczak, T.; Cybulska, J.; Podleśny, M.; Frąc, M. Various perspectives on microbial lipase production using agri-food waste and renewable products. Agriculture 2021, 11, 540. [CrossRef]

36. Membrillo, I.; Sánchez, C.; Meneses, M.; Favela, E.; Loera, O. Effect of substrate particle size and additional nitrogen source on production of lignocellulolytic enzymes by Pleurotus ostreatus strains. Bioresour. Technol. 2008, 99, 7842-7847. [CrossRef] [PubMed]

37. Smail, T.; Salhi, O.; Knapp, J. Solid-state fermentation of carob pods by Aspergillus niger for protein production: Effect of particle size. World J. Microbiol. Biotechnol. 1995, 11, 171-173. [CrossRef]

38. Osmolovskiy, A.A.; Baranova, N.A.; Kreier, V.G.; Kurakov, A.V.; Egorov, N.S. Solid-state and membrane-surface liquid cultures of micromycetes: Specific features of their development and enzyme production (a review). Appl. Biochem. Microbiol. 2014, 50, 219-227. [CrossRef]

39. Stredansky, M.; Conti, E. Succinoglycan production by solid-state fermentation with Agrobacterium tumefaciens. Appl. Microbiol. Biotechnol. 1999, 52, 332-337. [CrossRef] [PubMed]

40. Benabda, O.; M'hir, S.; Kasmi, M.; Mnif, W.; Hamdi, M. Optimization of protease and amylase production by Rhizopus oryzae cultivated on bread waste using solid-state fermentation. J. Chem. 2019, 2019. [CrossRef]

41. Yu, X.H.; Gu, Z.X.; Tu, K.; Shao, R.; Jin, X.J. Optimization of solid-state fermentation media for soluble dietary fiber production by Hericium erinaceus. In Advanced Materials Research; Trans Tech Publications Ltd.: Freienbach, Switzerland, 2012; pp. 81-89.

42. Bellettini, M.B.; Fiorda, F.A.; Maieves, H.A.; Teixeira, G.L.; Ávila, S.; Hornung, P.S.; Júnior, A.M.; Ribani, R.H. Factors affecting mushroom Pleurotus spp. Saudi J. Biol. Sci. 2019, 26, 633-646. [CrossRef] [PubMed]

43. Lin, T.-Y.; Tseng, A.-J.; Chao, C.-H.; Lu, M.-K. Microelements induce changes in characterization of sulfated polysaccharides from Antrodia cinnamomea. Int. J. Biol. Macromol. 2018, 120, 952-958. [CrossRef] [PubMed]

44. Li, I.-C.; Chen, Y.-L.; Lee, L.-Y.; Chen, W.-P.; Tsai, Y.-T.; Chen, C.-C.; Chen, C.-S. Evaluation of the toxicological safety of erinacine A-enriched Hericium erinaceus in a 28-day oral feeding study in Sprague-Dawley rats. Food Chem. Toxicol. 2014, 70, 61-67. [CrossRef] [PubMed] 